\title{
СПІВВІДНОШЕННЯ ДЕФІНІЦІЙ «РЕГІОН», «РЕГІОНАЛІЗАЦІЯ», «ПАРАДИПЛОМАТІЯ» В КОНТЕКСТІ ДОСЛІДЖЕННЯ ЗОВНШШНЬОЇ ДІЯЛЬНОСТІ СУБНАЦІОНАЛЬНИХ ОДИНИЦЬ
}

Головко I. К.

\section{ВСТУП}

Особливості співробітництва та динаміка розвитку відносин між суб'єктами міжнародних відносин відбувається не лише під впливом процесів глобалізації, а й регіоналізації, інтернаціоналізації, глокалізації та фрагментації, які стали своєрідною відповіддю на делегування значних повноважень наднаціональним утворенням. Останнім часом активна участь регіонів у міжнародних відносинах перетворилась на стійку тенденцію світової політики.

Активна участь регіонів у міжнародних відносинах $\epsilon$ частиною більш загального процесу регіоналізації. Активними учасниками процесів регіоналізації виступають як субнаціональні регіони, які сформувалися внаслідок національно-етнічного поділу, так і регіони, які були створені з метою транскордонного співробітництва. 3 одного боку, така активність регіонів кидає виклик монополії держави на здійснення зовнішніх функцій, а також призводить до нових підходів до трактування меж суверенітету та цілісності національної держави. На думку сучасних політологів, процеси, що відбуваються сьогодні, послаблюють повноваження центральних органів влади, що означає падіння рівня безпеки і зростання інших захисних структур, у тому числі корпоративних, етнічних і регіональних.

Очевидно, що регіоналізація - це об'єктивний процес, який відповідає на виклики глобалізації і $€$ невід'ємною частиною демократичних реформ. Завдяки регіоналізації відбувається формування громадянського суспільства за рахунок становлення «горизонтальних» соціальних структур, здатних забезпечити незалежність індивідів і суспільних груп від держави, забезпечити механізм зворотного зв'язку між суспільством і держапаратом. У цьому контексті регіоналізація розглядається як один із засобів формування таких «горизонтальних» структур, які неминуче 
призводять до появи системи «стримувань і противаг» у відносинах між центром і регіонами. У політиці вже не $\epsilon$ визначальним процес передачі на регіональний рівень прийнятих у центрі рішень, а, навпаки, починає домінувати переговорний процес між ланками мережі політичних інститутів.

У цих умовах сформувалася нова реальність, коли регіональні утворення вимагають більше прав для здійснення самоуправління та виходу на міжнародну арену. Саме ці прагнення і стимулювали виникнення принципово нової форми міжнародного співробітництва в умовах процесів регіоналізації - парадипломатії. Парадипломатія $\epsilon$ прикладом ефективного інструменту субнаціональних одиниць для підвищення їх самоврядування з метою формування образу регіону як повноцінного політичного утворення, яке функціонує самостійно, без вказівки з боку центральної влади та вирішує питання щодо власного розвитку.

Дослідники міжнародних відносин дотримуються різних точок зору, вивчаючи феномен «парадипломатії» як різновид політичної комунікації, зміст якої проявляється в самостійній міжнародній діяльності, здійснюваній регіональною владою для досягнення своїх політичних, економічних, культурних або інших цілей у межах взаємодії з іноземними державами або регіонами. Така міжнародна діяльність може підтримувати, доповнювати, коригувати та дублювати національно-державну дипломатію, а іноді й суперечити ӥй.

У сучасному науковому дискурсі існує плюралізм думок, що спричиняє бурхливі академічні дискусії щодо інтерпретації різних суспільно-політичних явищ, які розглядаються крізь призму різних підходів. Тож доцільно розглянути співвідношення ключових дефініцій «регіон», «регіоналізація» та «парадипломатія» в контексті дослідження діяльності субнаціональних акторів на міжнародній арені.

\section{1. Визначення категорії «регіон» у сучасній політичній науці}

У політичних студіях під час визначення поняття «регіон» в основному виходять із розуміння його як внутрішньодержавної політичної одиниці. У внутрішньополітичних відносинах у державах, побудованих на основі федералізму або регіоналізму, виділяються три рівні державного управління: національний, регіональний та місцевий. Через таке розуміння «регіон» визначається як інституційна одиниця, конкретна територія, для якої характерна наявність власних органів 
політичної влади, нормативно-правове врегулювання взаємовідносин 3 іншими рівнями політичної влади ${ }^{1}$.

Категорія «регіон» у теорії міжнародних відносин може також визначатися як категорія, що тотожна дефініції «актор міжнародної діяльності». Водночас серед спеціалістів 3 питань міжнародних відносин та геополітики регіоном зазвичай передусім називають групу країн, які пов'язані між собою більше, ніж 3 іншими країнами. Держави, об'єднані в такий регіон, мають певні інтегративні особливості, такі як схожість організації економічної діяльності, територіальна близькість та ін. Для виключення колізій у трактуванні поняття «регіон» як складової частини структури держави і як актора міжнародних відносин дослідники П. Сміт, Д. Меррілл, Т. Кон, П. Циганков додають уточнюючі визначення, такі як «внутрішньодержавний регіон» чи «субнаціональні актори». У такому разі дефініція «регіон» інтерпретується в такому ж ключі, як це відбувається під час застосування політологічного підходу: як наявність інституціоналізованого співтовариства всередині іншого інституціоналізованого суспільства (держави) ${ }^{2}$.

Дослідники регіональних процесів загалом та парадипломатії зокрема у своїх роботах роблять спроби конкретизувати поняття «регіон». Наприклад, А.С. Кузнєцов задля конкретизації даної категорії виділяє дві основні стратегії в цьому контексті, де перша стратегія, на його думку, зводиться до спроби створити синтетичне визначення, а друга полягає в більш вузькому трактуванні терміна «регіон», що передбачає запровадження додаткових дефініцій, які більш детально розкривають його зміст ${ }^{3}$. У цьому контексті дослідник запозичує дані визначення як із вітчизняної, так і з закордонної політичної науки i наводить такі поняття, як: «простір» (area), що визначає неінституціоналізовані регіони, «субфедеральна одиниця» (federated constituent) i «нецентральний уряд» (non-central government).

${ }^{1}$ Kuznetsov A. Theory and Practice of Paradiplomacy: Subnational Governments in International Affairs. London : Routledge, 2015. 184 p.

2 Головко I. Теоретичні основи дослідження парадіпломатії як форми міжнародного співробітництва. URL: http://sis-journal.com/wp-content/uploads/ 2018/10/Slovak-international-scientific-journal-№21-2018.pdf

${ }^{3}$ Кузнецов А. Дискурс парадипломатии. Дискурс-Пи. 2010. № 1-2. С. 353354. 
«Субфедеральна одиниця» як дефініція була запропонована американським дослідником Дж. Кінкейдом ${ }^{4}$. У подальшому в науковій літературі поняття «субфедеральна одиниця» також використовувалось ученими-політологами Б. Штульбегом i В. Введенським ${ }^{5}$. Зазначене поняття носить занадто вузький характер, що зводить політологічне розуміння поняття «регіон» до терміна «суб'єкт федерації». Зовсім іншим у концептуальному плані $\epsilon$ категорія «нецентральний уряд» (non-central government), яка була запропонована М. Кітінгом ${ }^{6}$. Ця дефініція, окрім того що вказує на інституційний характер регіону, ще й дає змогу застосувати дане визначення до категорії адміністративно-територіальної одиниці як унітарної держави, так і федерації. Однак якщо ключовим недоліком визначення «субфедеральна одиниця» $\epsilon$ його вузькість, то термін «нецентральний уряд» носить недостатньо конкретний характер. Як «нецентральну владу» можна розуміти власне владу на регіональному рівні, так і на рівні місцевого самоврядування. Це стосується і поняття «локальний уряд» (local government), що запропоноване М. Гудерьяном, який використовує цю дефініцію як для визначення процесів на рівні регіону, так і на рівні муніципалітетів ${ }^{7}$.

А. Лекур запропонував найбільш вдалі $з$ точки зору залучення комплексу принципових факторів варіанти конкретизації поняття «регіон», використавши поняття «субнаціональний актор» (subnational actor) та «субнаціональна одиниця» (subnational unit), які він запропонував використовувати як синоніми «регіону» ${ }^{8}$. Таке визначення «регіону» вказує саме на те, що з ієрархічної точки зору регіон має наступний рівень після державного. Схоже визначення наводиться і в Декларації з регіоналізму в Свропі, прийнятій на Асамблеї Регіонів Свропи (АРС) 4 грудня 1996 року в Базелі. У цьому документі категорія «регіон» визначається як «територіальне

${ }^{4}$ Kincaid J. Foreign Relations of Constituent Units : Working Paper. Forum of Federations. Winnipeg, 2001. $451 \mathrm{p}$.

5 Штульберг Б. Введенский В. Региональная политика России: теоретические основы, задачи и методы реализации. Москва : Гелиос АРВ, 2000. 208 с.

6 Keating M. Paradiplomacy and regional networking. URL: http://www.forumfed.org/libdocs/ForRelCU01/924-FRCU0105-eu-keating.pdf

7 Головко I. Теоретичні основи дослідження парадіпломатії як форми міжнародного співробітництва. URL: http://sis-journal.com/wp-content/uploads/ 2018/10/Slovak-international-scientific-journal-№21-2018.pdf

${ }^{8}$ Lecours A. Paradiplomacy and Stateless Nations: a Reference to the Basque Country. URL: http://digital.csic.es/bitstream/10261/1472/1/dt-0106.pdf 
утворення державного законодавства, що має рівень, наступний за рівнем держави, і має політичне самоврядування» ${ }^{9}$. Істотні ознаки регіону також закріплюються цим документом. Загалом, у документі визначається, що таке явище, як регіон, повинно бути визнано конституцією або іншими законами; його повноваження, ідентичність, форма управління та автономія мають бути гарантовані; також регіон повинен мати власну конституцію, статут автономії чи інший закон, який би був частиною правової структури держав; регіон повинен висловлювати власну політичну ідентичність, яка може бути забарвлена в найрізноманітніші політичні форми.

Отже, після детального аналізу різних підходів до визначення сутності категорії «регіон» можна зазначити, що він має розглядатися як безпосередній субнаціональний актор i водночас має бути визначений як територіально-політичне утворення, що функціонує на регіональному рівні. Також потрібно відзначити, що визнання регіону як субнаціонального актора внутрішньополітичних i зовнішньополітичних відносин не означає заперечення його культурноісторичної самобутності й економічної самостійності.

Варто відмітити, що дослідження міжнародних відносин залишаються тією дослідницькою сферою, для котрої притаманна критика наявних та перманентний пошук нових наукових підходів. Пов'язано це з тим, що об'єкт дослідження міжнародних відносин не $\epsilon$ статичним, він знаходиться в процесі постійних змін. Сукупність теоретичних підходів у дослідженні міжнародних відносин представляє собою досить мозаїчний конгломерат.

Традиційно міжнародні відносини досліджувалися 3 точки зору реалізму та ідеалізму. Водночас 3 1980-х рр. минулого століття в міжнародно-політичній теорії з'являються сумніви в ефективності методу, в основу якого покладена віра в раціональне знання, та можливості виявлення найвиразніших тенденцій міжнародного розвитку. 3 того часу починають активно залучатися нові підходи, такі як неореалізм, неолібералізм, функціоналізм, конструктивізм та інші.

Останне десятиріччя XX i початок XXI ст. стали періодом бурхливого розвитку конструктивізму - нової течії в міжнароднополітичній науці. Видатними представниками цього напряму

9 Головко І. Процеси глобальної регіоналізації як компонент глобалізаційних процесів постбіполярної доби. Гілея: науковий вісник. 2017. Вип. 121. С. 195-199. 
виступають Н. Онуф, К. Реус-Сміт та А. Вендт ${ }^{10}$. Увага, яку конструктивісти приділяють тому, що вони називають co-constitution, тобто взаємному формуванню інститутів і агентів, пріоритет, який вони віддають конститутивним функціям правил i норм над регулюючими, - все це має досить серйозні підстави для інтерпретації міжнародних відносин. Тобто конструктивісти припускають імовірність змін у фундаментальних засадах функціонування міжнародних відносин і світової політики.

Згідно з конструктивізмом, поки планета інституційно розділена на держави, вони як міжнародні актори збережуть особливу роль у світовій політиці. Однак, незважаючи на це, не можна стверджувати, що держави успішно виконують свої завдання (забезпечення безпеки і добробуту громадян, індивідуальних прав і свобод тощо), а навпаки, стає зрозуміло, що держава як форма політичної організації в цілому все очевидніше демонструє свою дисфункцію. Разом із тим конструктивісти вважають, що впливовими акторами можуть виступати не тільки національні держави, а також і регіональні утворення, політичні, професійні та інші еліти, мережі неурядових організацій, експертні співтовариства, соціальні рухи, приватні особи тощо, звертаючи увагу на необхідність урахування, збільшення кількості механізмів зміни міжнародних відносин. Останні в результаті призвели до виникнення та поширення таких понять, як субнаціональний актор, регіон та регіоналізація. У межах даного дослідження особливий інтерес викликає саме тлумачення конструктивістами поняття «регіон» і їхня оцінка причин виникнення субнаціональних акторів та їхньої діяльності на міжнародній арені.

Аналізуючи регіони як одного із гравців на міжнародній арені, варто насамперед визначити сутність поняття «регіон». Якщо об'єктом вивчення загальної регіоналістики $є$ «регіон як самостійна просторовогеографічна, адміністративно-територіальна, інституціональнополітична, дипломатична, економічна, соціальна, історико-культурна, етнічна і демографічна величина», то об'єктом вивчення міжнароднополітичної регіоналістики $є$ регіональна державна політика i дипломатія, а також політична сфера регіональних спільностей ${ }^{11}$.

${ }^{10}$ Wendt A. Social theory of international politics. Cambridge University Press, 1999. P. 8-15.

11 Kuznetsov A. Theory and Practice of Paradiplomacy: Subnational Governments in International Affairs. London : Routledge, 2015. 184 p. 
Предмет міжнародно-політичної регіоналістики повязаний iз закономірностями становлення та розвитку політичної влади в регіонах, взаємного впливу державної політики на регіони і політики регіонів - на державу, а також із закономірностями функціонування політичної сфери життя регіональної спільності [9]. Одним із найбільш яскравих проявів регіоналізації стала тенденція зростання ролі субнаціональних акторів у міжнародних і дипломатичних системах, чому присвячують свої роботи Іво Духачек та П. Солдатос.

\section{2. Підходи до інтерпретації дефініції «регіоналізація» у сучасному науковому дискурсі}

У теоріях міжнародних відносин міжтериторіальне співробітництво і регіональна інтеграція розуміються по-різному. У класичних теоріях, таких як реалізм та лібералізм, внутрішньодержавні регіони не визнаються акторами міжнародних відносин, а процеси міждержавної інтеграції найчастіше аналізуються 3 позицій функціоналізму і міжурядового підходу. 3 точки зору функціоналістів, парадипломатія- це регіональна реакція на імперативи глобалізації та економічної взаємозалежності ${ }^{12}$. На думку одного 3 найбільш радикальних учених-гіперглобалістів К. Омає, 3 огляду на невблаганний занепад держав-націй вони замінюються регіонамидержавами. Це означає, що динамічні субнаціональні економіки виявляються більш функціональними в цьому новому циклі глобальної економіки. Також, на думку К. Омає, коріння занепаду національних держав лежать в їхній зростаючій нездатності сприяти зростанню, соціальному добробуту та його розподілу, а також їхній нездатності контролювати обмінні курси і захищати ринки капіталу ${ }^{13}$. Економічна $\mathrm{i}$ технологічна глобалізація заохочуе самоврядні територіальні утворення проводити певну політику, захищаючи і просуваючи власні інтереси, цінності та ідентичність, а також сприяти глобальним цілям солідарності, миру, розвитку або культурного плюралізму ${ }^{14}$. Глобалізація відкриває для регіонів можливість побудови зовнішньої

12 Grydehoj A. Challenges to Local Government Innovation: Legal and Institutional Impediments to the Exercise of Innovative Economic Development Policy by Subnational Jurisdictions. London, 2013. P. 1-21.

${ }^{13}$ Головко I. Теоретичні основи дослідження парадіпломатії як форми міжнародного співробітництва. URL: http://sis-journal.com/wp-content/uploads/ 2018/10/Slovak-international-scientific-journal-№21-2018.pdf

14 Kuznetsov A. Theory and Practice of Paradiplomacy: Subnational Governments in International Affairs. London : Routledge, 2015. 184 p. 
політики з урахуванням специфіки розвитку кожної території та сприяє оптимальному проведенню зовнішньої політики, збільшенню потужності держави на світовій арені. Під впливом глобалізації відбувається зростання самостійності регіонів, що сприяє підвищенню їхньої конкурентоспроможності в цілому.

На сучасному етапі розвитку міжнародних відносин поняття «регіоналізм» і «регіоналізація» фактично є ідентичними. У більш загальному вигляді - дані концепції мають на меті допомогти вивчити природу регіонального співробітництва. Їхні відмінності полягають у тому, що концепція регіоналізації робить акцент на визначенні регіональної інтеграції як процесу, тоді як концепція регіоналізму вивчає теоретичний складник даного явища ${ }^{15}$.

Вивчаючи проблему регіоналізації, необхідно відзначити, що в роботах західних вчених регіони розглядаються як гомогенні території, котрі мають відокремлені фізичні та культурні ознаки, що відрізняються від суміжних територій, з якими вони мають спільний кордон. Водночас регіони визначаються як невід'ємна складова частина національної території, з якою вони тісно пов'язані, а також мають чітке розуміння власних традицій та системи цінностей, поряд із власною індивідуальністю ${ }^{16}$. Європейська хартія територіального самоврядування, яка $\epsilon$ додатком до прийнятої Європейським парламентом Резолюції про регіональну політику Співтовариства та про роль регіонів, у ст. 1 має конкретне визначення поняття «регіон»: «це територія, яка в географічному плані $є$ абсолютно цілісним, або ж $є$ однорідним комплексом територій, які створюють замкнуте коло, для населення якого характерні спільні елементи, причому деякі її ознаки це утворення хотіло б закріпити i розширити, для того щоб стимулювати культурний, соціальний та економічний прогрес» ${ }^{17}$.

Поняття «регіоналізм» безпосередньо пов'язано 3 категорією «регіоналізація». Регіоналізм є складним дискусійним явищем, яке доволі часто використовується як синонім дефініції «регіоналізація», не враховуючи існування суттєвих відмінностей між цими поняттями. Регіоналізм стосується практичного аспекту перерозподілу певних

${ }^{15}$ Грачевська Т. Парадипломатія європейських регіонів: досвід для України. URL: http://www.dbuapa.dp.ua/Konf/konf_dridu/2014_05_15_mat er_pei.pdf

${ }^{16}$ Lecours A. When Regions Go Abroad: Globalization, Nationalism and Federalism. URL: http://www.pinkcandyproductions.com/portfolio/conferences/ globalization/pdfs/ lecours.pdf

17 Головко I. Теоретичні основи дослідження парадіпломатії як форми міжнародного співробітництва. URL: http://sis-journal.com/wp-content/uploads/ 2018/10/Slovak-international-scientific-journal-№21-2018.pdf 
владних повноважень центрального уряду, що відбувається 3 метою надання територіальним інституціям статусу, що $є$ проміжним між місцевим та центральним рівнями; регіоналізація у свою чергу стосується процесу, завдяки якому центральні адміністративні та політичні інституції відповідають на виклики, що виникають на регіональному рівні. Існує припущення, що витоки регіоналізму беруть початок із периферії, а, відповідно, регіоналізація є відповіддю з боку центру.

Відомий науковець Я.Г. Машбіц дає таке визначення цього явища: «Регіоналізмом визначається факт існування в країні районів зі значними соціальними, природними, етнокультурними та господарськими розбіжностями. Однак найважливішим аспектом регіоналізму є усвідомлення населення того чи іншого району, що цей конкретний район - їхня батьківщина. Водночас мешканці того чи іншого району тісними зв'язками економічного i насамперед духовного та культурного характеру нерозривно пов'язані з ним.

Великий тлумачний словник сучасної української мови, публікацію якого розпочала Академія наук України у 2010 році, визначає регіоналізм як «підхід до розгляду і вирішення яких-небудь проблем 3 позиції інтересів регіону» та регіоналізацію як «здійснення політики регіоналізму» $^{18}$.

Українська вчена Г.П. Щедрова розглядає регіоналізм як «політику, що враховує економічні, етнополітичні, національні та інші особливості, які притаманні певному регіону будь-якої країни, спрямовану на об’єднання груп певного регіону, що залежать одна від одної в аспектах економіки, політики та військової справи» ${ }^{19}$.

Потрібно окремо відзначити, що регіоналізм - це головним чином явище, що передбачає наявність відповідних адміністративнотериторіальних структур 3 їхніми особливими політичними, економічними, етнічними, соціальними та іншими відмінностями, що можуть відстоювати та захищати регіональні інтереси у владних інституціях держави. Ключовим аспектом регіоналізму $є$ наявність відповідних ознак, які регулюють відносини між регіонами та центром.

У свою чергу регіоналізація $\epsilon$ процесом формування та розвитку регіонів як відповідних суб'єктів, що мають нижчий рівень за

${ }^{18}$ Грачевська Т. Парадипломатія європейських регіонів: досвід для України. URL: http://www.dbuapa.dp.ua/Konf/konf_dridu/2014_05_15_mat er_pei.pdf

19 Шлапеко Е. Конструирование региональной идентичности в Северной Европе: институты и инструменты. Человек. Сообщество. Управление. 2015. C. $27-38$. 
національний, мають власну систему виконавчої влади, що вирізняється самостійністю та незалежністю від центральних державних органів влади, та власні органи та інституції самоврядування. У країнах, де функціонують регіони, наділені певними владними повноваженнями, регіоналізація стає віддзеркаленням процесу, що відповідає на прояви такого не простого явища, як регіоналізм ${ }^{20}$.

Як процес становлення та розвитку адміністративно-територіальної одиниці регіоналізація об'єднує у своїй цілісності політичні, економічні, національні, культурні та інші явища, що характеризуються власними специфічними особливостями, а також систему взаємовідносин, які відбуваються між людьми, політичними утвореннями, владними структурами та соціальними групами ${ }^{21}$.

Окремо потрібно відзначити той факт, що реалізація процесів регіоналізації відбувається в таких формах: шляхом виділення адміністративних регіонів усередині країни (регіоналізація зверху); організації самокерованої громади або появи нового регіону всередині існуючої адміністративної структури, відмінної від оточуючих (регіоналізація знизу); формування транскордонних регіонів і блоків країн або асоціацій регіонів (контрактно-горизонтальна регіоналізація). Отже, проблема регіоналізації $\epsilon$ проблемою виявлення спільних тенденцій у процесах генези регіонів в умовах глобалізації ${ }^{22}$.

В умовах «фрагментації зовнішньополітичної діяльності» значний інтерес представляє діяльність «гібридних» форм недержавних акторів, до яких слід відносити глобальні міста і внутрішньодержавні регіони, або регіони-держави. Внутрішньодержавні регіони можуть займати прикордонне розташування і утворювати транскордонні регіони 3 прикордонними територіями сусідньої держави. Такі транскордонні структури виявляють сьогодні найбільшу активність у вирішенні регіональних та глобальних питань, прагнучи таким чином адаптуватися до зовсім іншої політичної реальності і знайти новий політичний статус. Як справедливо у зв'язку 3 цим зазначає вченийполітолог, що займається дослідженням питань регіоналізації,

20 Штульберг Б. Введенский В. Региональная политика России: теоретические основы, задачи и методы реализации. Москва : Гелиос АРВ, 2000. $208 \mathrm{c}$.

${ }^{21}$ Lecours, A. Paradiplomacy and Stateless Nations: a Reference to the Basque Country. URL: http://digital.csic.es/bitstream/10261/1472/1/dt-0106.pdf

${ }^{22}$ Lecours A. When Regions Go Abroad: Globalization, Nationalism and Federalism. URL: http://www.pinkcandyproductions.com/portfolio/conferences/ globalization/pdfs/ lecours.pdf 
Ю. Царікаєв, «посилення ролі регіонів у сучасному світі дає підставу говорити про можливість появи в їхній особі нових політикотериторіальних утворень і становлення їх як суб'єктів регіональної економічної політики і міжнародних відносин» ${ }^{23}$.

Отже, регіони «нарощують експансію поза державою, ставлячи перед собою амбітні економічні, культурні та політичні завдання», стаючи «менш керованими в межах національних економік», маючи всі стимули конкурувати 3 державою на європейському і світовому ринках.

\section{3. «Парадипломатія» як відповідь на інтенсифікацію процесів регіоналізації}

Ключовим механізмом входження субнаціональних акторів у міжнародні відносини виступає парадипломатія. Парадипломатія $\epsilon$ відносно новим поняттям у світовій політиці, проте, як зазначає Дж. Розенау, вона демонструє стійку тенденцію поділу міжнародної політики на «два світи» - державних i недержавних акторів. Парадипломатія проявляється в активізації діяльності субнаціональних акторів, тобто внутрішньодержавних, прикордонних регіонів на світовій арені, при цьому кожен із них орієнтується на тісні зовнішньоекономічні, політичні культурні та інші зв'язки $з$ різними закордонними країнами і має свої специфічні форми представлення на міжнародній арені ${ }^{24}$.

У вітчизняній та закордонній літературі відомий постулат про те, що «демократія в цілому сприяє скороченню розміру юрисдикцій». Зазвичай демократизація та лібералізація ведуть до адміністративної та урядової децентралізації в національних державах. Отже, парадипломатія більш поширена в країнах, в яких є ринкова економіка, демократично обраний державний уряд, обраний субнаціональний уряд i чиновники місцевих органів влади, а також конкуруючі політичні партії та механізми захисту прав людини, включаючи право власності.

Основними мотивами парадипломатичної діяльності, на думку представника північноамериканської школи Іво Духачека, є політика,

${ }^{23}$ Ціватий В. Глобалізація та європейська регіональна політика: історичні імперативи і сучасність. Науковий вісник Дипломатичної академії Украӥни. Київ, 2012. С. 20-26.

Головко I. Процеси глобальної регіоналізації як компонент глобалізаційних процесів постбіполярної доби. Гілея: науковий вісник. 2017. Вип. 121. С. 195-199. 
економіка, культура та екологія ${ }^{25}$. Політичні мотиви можуть бути спрямовані не тільки на залучення уваги центральної влади і міжнародного суспільства, але й носити сепаратистський характер. Американський дослідник Дж. Кінкайд підкреслює, що вирішення проблеми сепаратизму полягає не в придушенні міжнародної активності регіону, а в першочерговому вирішенні внутрішньодержавних протиріч. Умовою ефективної регіональної політики центру стають демократичні механізми іiі реалізації, які передбачають «відповідність проведених заходів інтересам і очікуванням регіональних спільнот» ${ }^{26}$.

Міжнародна активність регіонів залежить від їхніх структурних можливостей (внутрішньодержавних i міжнародних), які можуть змінювати мотиви та стратегії регіонів. Внутрішньодержавні можливості мають на увазі рівень автономії, який визначається формою державного устрою, конституцією й іншими нормативноправовими документами. До класифікації внутрішньодержавних можливостей слід додати географічне положення і ресурси регіону (природні, трудові, економічні та ін.). До міжнародних можливостей регіонів британський вчений М. Кітінг відносить глобалізацію, ускладнення міжнародних відносин i зниження ролі держави: «капітали, товари, послуги i, в меншій мірі, люди знайшли мобільність, їх неможливо утримувати в межах однієї держави» ${ }^{27}$.

Автор терміна «парадипломатія» Іво Духачек стверджував, що субнаціональна влада для проведення своєї політики на міжнародній арені використовує певні механізми («канали участі»): відкриття постійних представництв регіонів, ділові поїздки за кордон і участь у конференціях представників місцевих органів влади, проведення міжнародних торговельних і промислово-інвестиційних виставок ${ }^{28}$. М. Кітінг у свою чергу поділив канали участі на дві форми міжнародної взаємодії - двостороннє партнерство і міжрегіональну мережеву співпрацю. Двостороннє партнерство реалізується між регіонами, штучно розділеними кордонами, а міжрегіональна

${ }^{25}$ Грачевська Т. Парадипломатія європейських регіонів: досвід для України. URL: http://www.dbuapa.dp.ua/Konf/konf_dridu/2014_05_15_mat er_pei.pdf

${ }^{26}$ Kincaid J. Foreign Relations of Constituent Units : Working Paper. Forum of Federations. Winnipeg, 2001. 451 p.

27 Keating M. Paradiplomacy and regional networking. URL: http://www.forumfed.org/libdocs/ForRelCU01/924-FRCU0105-eu-keating.pdf

28 Головко I. Теоретичні основи дослідження парадіпломатії як форми міжнародного співробітництва. URL: http://sis-journal.com/wp-content/uploads/ 2018/10/Slovak-international-scientific-journal-№21-2018.pdf 
співпраця в мережі здійснюється регіонами без спільного кордону, але зі схожими цілями і завданнями розвитку місцевої громади та регіональної економіки. Головний механізм реалізації мережевої співпраці - створення міжрегіональних асоціацій, які стають майданчиком для спілкування та знаходження контактів. Виходячи 3 ідей британського політолога М. Кітінга, під час аналізу відносин між центром і регіонами необхідно звертатися до правових і політичних чинників взаємин, віддаючи перевагу останнім, шляхом спостереження за «зміною ставлення до парадипломатії в разі зміни регіональних еліт» ${ }^{29}$.

Представник теорії парадипломатії А. Лекур вказує на відсутність теоретичних пояснень «методів створення акторів світової політики, факторів, що впливають на їхню поведінку і формулювання стратегії міжнародної діяльності ${ }^{30}$. Теорія конструктивізму істотно доповнює концепцію парадипломатії. У центрі конструктивістської парадигми взаємодія агентів (акторів), головним чином держав, що створюють соціальну реальність у макро- і мікроструктурному середовищі, тобто на глобальному і регіональному рівні. Виходячи із системного підходу, в транскордонному співробітництві (мікроструктурний рівень) можна виділити такі його елементи - внутрішньодержавні регіони і міста, внутрішню структуру - міжрегіональні зв'язки, зовнішню структуру взаємодію між державами (макроструктурний рівень). На активність міжнародного співробітництва регіонів впливають різні мікро- i макроструктурні фактори зовнішнього середовища ${ }^{31}$. Норми міжнародного права, що регулюють транскордонне співробітництво, основні принципи співпраці в межах регіональних організацій, інструменти підтримки транскордонного співробітництва утворюють групу макроструктурних факторів.

Американський конструктивіст А. Вендт у своїх дослідженнях вказує, що «характер міжнародного життя визначається переконанням і очікуванням, які агенти мають один про одного, і це встановлюється соціальними, а не матеріальними структурами». У понятті «агент» відбивається соціальний i культурний контроль системи над індивідами та/або соціальними спільнотами й роль, яку вони прагнуть

29 Keating M. Paradiplomacy and regional networking. URL: http://www.forumfed.org/libdocs/ForRelCU01/924-FRCU0105-eu-keating.pdf

${ }^{30}$ Lecours A. Paradiplomacy and Stateless Nations: a Reference to the Basque Country. URL: http://digital.csic.es/bitstream/10261/1472/1/dt-0106.pdf

31 Головко I. Теоретичні основи дослідження парадіпломатії як форми міжнародного співробітництва. URL: http://sis-journal.com/wp-content/uploads/ 2018/10/Slovak-international-scientific-journal-№21-2018.pdf 
(свідомо чи несвідомо) грати відповідно до очікувань оточуючих, заснованих на соціальному статусі агента ${ }^{32}$.

Як зазначає дослідниця транскордонної регіоналізації Е. Шлапеко, отримання статусу агента відбувається через соціалізацію, інтернаціоналізацію і культурний відбір. Стосовно формування транскордонних регіонів це виглядає так ${ }^{33}$.

Соціалізація - включення регіонів у систему взаємовідносин усередині міжнародного суспільства за допомогою як переконання, так i «нормативного тиску». Регіональній інтеграції сприяе i процес вестернізації, який має на увазі адаптацію західних норм, рішень, цінностей через інституційну співпрацю між національними та субнаціональними акторами. До норм, що регулюють способи поведінки, можна віднести міжнародні угоди й конвенції, правила участі в субрегіональних організаціях, якими є, наприклад, Мадридська конвенція 1980 року, Європейська хартія місцевого самоврядування 1985 року. Конструктивісти описують соціалізацію за допомогою таких понять, як «інтерсуб'єктивність» (загальне розуміння, єдність ідей в області міжнародних відносин) та «ідентичність» (самопредставлення, самосприйняття i несхожість індивіда 3 іншими $)^{34}$.

Одним із найважливіших для конструктивістського підходу $\epsilon$ співвідношення понять інтересу й ідентичності агента. Поняття про інтереси та вподобання агентів дають ідентичності, які відображаються в соціальних подіях, нормах і процесах.

Формування регіональної ідентичності - одна 3 основ «нового регіоналізму» та найвищий ступінь регіональної інтеграції за шкалою європейського політолога Б. Хеттне. Ідентичність формується в результаті повсякденної практики і контактів між індивідуумами різного рівня - від професійних політиків до простих жителів. Процеси регіоналізації окремих держав пов'язані не стільки з економічними

${ }^{32}$ Wendt A. Social theory of international politics. Cambridge University Press, 1999. P. 8-15.

33 Шлапеко Е. Конструирование региональной идентичности в Северной Европе: институты и инструменты. Человек. Сообщество. Управление. 2015. C. 27-38.

34 Головко I. Теоретичні основи дослідження парадіпломатії як форми міжнародного співробітництва. URL: http://sis-journal.com/wp-content/uploads/ 2018/10/Slovak-international-scientific-journal-№21-2018.pdf 
і політичними претензіями влади, скільки 3 культурною самоідентифікацією, збереженням традицій на даній території ${ }^{35}$.

Вчений-політолог А. Макаричєв розвиває концепцію «м'якого регіоналізму», згідно з якою істотний вплив на процес конструювання ідей i формування інституційної структури регіону має «епістемологічне співтовариство». Відповідно до теорії соціального капіталу «наявність сильної регіональної ідентичності сприяє економічному процвітанню» ${ }^{36}$. Однак створення регіональної ідентичності часто повязане 3 появою націоналістичних рухів і сепаратистських тенденцій. Як вважає французький науковець А. Лекур, націоналізм є найбільш важливим фактором, що визначає парадипломатію: «регіони із сильними націоналістичними рухами 3 більшою ймовірністю створять міжнародний імідж» 37 .

Щодо культурного складника, то еволюція агентів міжнародної системи супроводжується «культурним відбором» у формі імітації (одностороннього відтворення) успішного досвіду або навчання (двостороннього процесу, що вимагає взаємодії між джерелом досвіду і реципієнтом). У транскордонне співробітництво культурний відбір проходить через реалізацію проектів, створення спільних стратегій розвитку. Навчання може виражатися в участі регіонів у міжнародних організаціях, таких як Рада міністрів північних країн або Баренцевого регіону. Подібного роду організації акумулюють у собі інтелектуальний капітал, залучаючи до роботи експертне й наукове співтовариство. Обмін даними, проведення круглих столів і робочих зустрічей дозволяє знаходити рішення спільних проблем, а потім застосовувати напрацювання в регіонах. Важлива роль у цьому процесі відведена інститутам, кодифікованим у формальних нормах і правилах, але які мають мотиваційну силу тільки внаслідок соціалізації акторів і їхній участі в колективному знанні. До таких інститутів слід віднести офіційні відносини на основі угод, діяльність робочих груп, єврорегіонів та транскордонних регіонів.

35 Головко I. Процеси глобальної регіоналізації як компонент глобалізаційних процесів постбіполярної доби. Гілея: науковий вісник. 2017. Вип. 121. С. 195-199.

36 Головко I. Теоретичні основи дослідження парадіпломатії як форми міжнародного співробітництва. URL: http://sis-journal.com/wp-content/uploads/ 2018/10/Slovak-international-scientific-journal-№21-2018.pdf

37 Lecours A. When Regions Go Abroad: Globalization, Nationalism and Federalism. URL: http://www.pinkcandyproductions.com/portfolio/conferences/ globalization/pdfs/lecours.pdf 


\section{ВИСНОВКИ}

Більшість регіонів, що існують на сучасній міжнародній арені - це функціональні регіони, складові частини яких спочатку не обов'язково були схожі один з одним, а їх створення передбачало досягнення взаємодії та доповнення територіальних компонентів через інтеграцію. Безумовно, формування в регіоні ціннісної єдності, міцних комунікаційних зв'язків, зниження економічних диспропорцій сприяють створенню й укріпленню міжнародного порядку і безпеки. Натепер існує тенденція делегування значної частини владних повноважень субнаціональним регіонам та регіонам, які виникли внаслідок транскордонного співробітництва. Своєчасне виникнення та ефективна діяльність парадипломатії, що з'явилась разом із процесами регіоналізації, та їх безпосередній взаємозв'язок можна трактувати як відповідь на процеси інституціоналізації, глобалізації та регіоналізації, a самі процеси регіоналізації слід вважати чинником появи парадипломатії. Також варто зазначити, що парадипломатія використовує інструментарій, який не має суттєвих відмінностей від інструментарію класичної дипломатії. Основні підходи та механізми діяльності акторів парадипломатії, спрямовані на мобілізацію регіональних ресурсів, цілком себе виправдовують i сприяють реалізації ініціатив, покликаних забезпечити інтереси регіонів та їхніх громадян у сфері зовнішніх зносин.

Отже, категорії «регіон», «регіоналізація» і «парадипломатія», незважаючи на той факт, що вони пов'язані між собою, носять складний і неоднозначний характер. Прямий взаємозв'язок між цими поняттями зумовлений тим, що в основі парадипломатії лежить участь регіонів у процесах міжнародного співробітництва, що стало можливим завдяки поглибленню процесів регіоналізації на міжнародній арені. Водночас регіони реалізують власні амбіції виходу на міжнародну арену завдяки використанню інструментів парадипломатії. Тож категорії «парадипломатія», «регіоналізація» i «регіон» тісно взаємопов'язані й зумовлюють одна одну.

\section{АНОТАЦЯ}

У процесі дослідження було встановлено співвідношення дефініцій «регіон», «регіоналізація» і «парадипломатія» в сучасному науковому дискурсі. Проведене дослідження довело, що вказані дефініції перебувають у системній зумовленості, причому зв'язок між ними балансує, відображаючи реалії, між зміною тенденцій до утворення регіонів під випливом глобалізації і зворотного впливу глокалізації на регіоналізм як явище та регіоналізацію як процес, що у свою чергу 
запускає механізм парадипломатії. Категорії «парадипломатія» i «регіон» тісно взаємопов'язані й зумовлюють одна одну, є складними й неоднозначними. Прямий взаємозв'язок між цими поняттями зумовлений тим, що в основі парадипломатії лежить участь регіонів у процесах міжнародного співробітництва, тоді як регіони реалізують власні амбіції виходу на міжнародну арену завдяки використанню інструментів парадипломатії. Незважаючи на те, що парадипломатія створює певні складнощі для центральних урядів, в основному вона не призводить до збільшення конфліктів між регіоном і державою. Звичайно, держави можуть шукати способи для інтеграції парадипломатії в їхньому державному дипломатичному апараті та посилення їхньої ролі у вирішенні зовнішньополітичних цілей. Однак якщо регіон націлений на пошук шляхів відокремлення від своєї держави, ця інтеграція може виявитися практично неможливою. Таким чином, однією з передумов виникнення та формування парадипломатії були процеси регіоналізації, через те що саме нова конфігурація сил на міжнародній арені й дозволила розвиватися новій формі співробітництва - парадипломатії.

\section{ЛІТЕРАТУРА}

1. Акимов Ю.Г. Парадипломатия как средство выражения региональной идентичности субъектов федераций. Управленческое консультирование. 2016. № 2 (86). С. 25-33.

2. Головко I. Процеси глобальної регіоналізації як компонент глобалізаційних процесів постбіполярної доби. Гілея: науковий вісник. 2017. Вип. 121. С. 195-199.

3. Головко I. Теоретичні основи дослідження парадіпломатії як форми міжнародного співробітництва. URL: http://sis-journal.com/wpcontent/uploads/2018/10/Slovak-international-scientific-journal-№212018.pdf (дата звернення: 18.12.2018).

4. Грачевська Т. Парадипломатія європейських регіонів: досвід для України. URL: http://www.dbuapa.dp.ua/Konf/konf_dridu/2014_05_ 15_mat er_pei.pdf (дата звернення: 08.08.2017).

5. Грачевська Т. Парадипломатія як складова процесів регіоналізації на сучасному етапі. Грані. 2014. № 12. С. 77-82.

6. Кузнецов А. Дискурс парадипломатии. Дискурс-Пи. 2010. № 1-2. С. 353-354.

7. Ціватий В. Глобалізація та європейська регіональна політика: історичні імперативи і сучасність. Науковий вісник Дипломатичної академії Украӥни. Київ, 2012. С. 20-26. 
8. Цыганков П. О содержании термина «международный актор»: вклад социологии. Материаль 4-го конвента РАМИ «Пространство и время в мировой политике и международных отношениях». Москва, 2007. C. $30-42$.

9. Шлапеко Е. Конструирование региональной идентичности в Северной Европе: институты и инструменты. Человек. Сообщество. Управление. 2015. С. 27-38.

10. Штульберг Б. Введенский В. Региональная политика России: теоретические основы, задачи и методы реализации. Москва : Гелиос APB, 2000. $208 \mathrm{c}$.

11. Grydehoj A. Challenges to Local Government Innovation: Legal and Institutional Impediments to the Exercise of Innovative Economic Development Policy by Subnational Jurisdictions. London, 2013. P. 1-21.

12. Keating M. Paradiplomacy and regional networking. URL: http://www.forumfed.org/libdocs/ForRelCU01/924-FRCU0105-eukeating.pdf (дата звернення: 15.11.2016).

13. Kincaid J. Foreign Relations of Constituent Units : Working Paper. Forum of Federations. Winnipeg, 2001. 451 p.

14. Kuznetsov A. Theory and Practice of Paradiplomacy: Subnational Governments in International Affairs. London : Routledge, 2015. 184 p.

15. Lecours A. Paradiplomacy and Stateless Nations: a Reference to the Basque Country. URL: http://digital.csic.es/bitstream/10261/1472/1/dt0106.pdf (дата звернення: 29.08.2018).

16. Lecours A. When Regions Go Abroad: Globalization, Nationalism and Federalism. URL: http://www.pinkcandyproductions.com/portfolio/ conferences/globalization/pdfs/ lecours.pdf (дата звернення: 11.11.2019).

17. Wendt A. Social theory of international politics. Cambridge University Press, 1999. P. 8-15.

\author{
Information about author: \\ Holovko I. K., \\ Candidate of Political Science, \\ Assistant of the Department of International Relations \\ Oles Honchar Dnipro National University \\ 72, Gagarin Av., Dnipro, Ukraine
}

